\title{
PROGRAM KEMITRAAN MASYARAKAT (PKM) PENINGKATAN KEMAMPUAN MENGAJAR UNTUK GURU-GURU SD DI KECAMATAN TOMOHON TENGAH KOTA TOMOHON
}

\author{
Katrina Siwi \\ Universitas Negeri Manado \\ siwikatrina@gmail.com
}

\begin{abstract}
Abstrak
Adapun tujuan dari Program Kemitraan Masyarakat ini adalah: 1). Mempersiapkan pemmbelajaran, termasuk mengenali karakteristik dan kebutuhan belajar peserta didik; 2). Menyususn rencana pembelajaran dengan menerapkan prinsip-prinsip pembelajaran dan keilmuan bidang studi dengan tepat; 3). Melaksanakan pembelajaran secara efektif dan efisien dengan mengacu pada rencana pembelajaran yang telah dibuat, 4) melaksanakan metode pembelajaran menggunakan media power point; dan 5). Melaksanakan kegiatan pembelajaran menggunakan media pembelajaran aktif. Kegiatan Program Kemitraan Masyarakat ini bertempat di Kecamatan Tomohon Tengah Kota Tomohon. Dengan menggunakan metode Pemberdayaan masyarakat partisipatif atau Participatory Rural Apraissal (PRA).

Hasil simpulan yang didapatkan dari Program Kemitraan Masyarakat ini bahwa Kegiatan PKM telah dilaksanakan dengan lancar dan baik serta telah memberikan pengetahuan dan keterampilan dalam bidang Penyusunan Rencana Pembelajaran, Pengembangan Metode Pembelajaran Aktif dan pengembangan Media Power Point dalam Pembelajaran. Para peserta yang merupakan Guru-guru SD di Kecamatan Tomohon Tengah Kota Tomohon terlihat antusias dalam berpartisipasi dikegiatan Pelatihan untuk Meningkatkan Kemampuan Mengajar Guru SD. Keberhasilan dalam PKM ini tercermin pada guru yang: a). memiliki pengetahuan dan pemahaman tentang metode pembelajaran aktif; (b) memiliki pengetahuan dan pemahaman tentang mengembangkan media powerpoint dalam pembelajaan; (c) memiliki pengetahuan, pemahaman dan praktik tentang menyususun Rencana Pembelajaran.
\end{abstract}

Kata kunci: Kemampuan, Guru SD, Kecamatan Tomohon Tengah

\section{PENDAHULUAN}

\section{Analisis Situasi}

Pendidikan adalah usaha sadar manusia untuk meningkatkan kulitas dirinya, baik personal maupun kolektif. Pendidikan juga merupakan suatu upaya manusia untuk memanusiakan dirinya dan membedakannya dengan makhluk lain. Untuk itu pendidikan menjadi penting, tatkala manusia berinteraksi dengan manusia lainnya dan pendidkanlah yang akan membedakan kualitas interaksi tersebut.Pendidikan sebagai sebuah proses sangat dipengaruhi oleh peranan guru, artinya, guru yang akan menentukan apakah proses pembelajaran yang dilakukan akan membawa hasil secara maksimal sebagaimana diharapkan, ataukah tidak [1].

Untuk mencapai kesuksesan dalam pelaksanaan tugasnya, seorang guru harus memahami terhadap kesuksesannya dalam mengajar. Salah satu aspek penting yang menentukan terhadap keberhasilan pembelajaran adalah kompetensi guru. Guru adalah pendidik professional dengan tugas utama adalah mendidik, mengajar, membimbing, melatih, dan mengevaluasi peserta didik pada pendidikan anak usia dini jalur pendidikan formal, pendidikan dasar 
dan pendidikan menengah. Ketegasan di atas menjelaskan bahwa guru harus memiliki sikap keprofesionalisme yang harus dimiliki. Profesional sendiri adalah suatu pekerjaan atau kegiatan yang dilakukan seseorang dan menjadi sumber penghasilan kehidupan yang memerlukan keahlian, kemahiran, atau kecakapan yang memenuhi standar mutu atau norma tertentu serta memerlukan pendidikan profesi.

Meningkatan kualitas pendidikan guru di tingkat Sekolah Dasar (SD) diharapkan mampu meningkatkan kemampuan profesional guru Sekolah dasar (SD) [2]. Mengingat profesi guru SD merupakan pekerjaan yang tidak mudah dilakukan kerena mengajar di Sekolah Dasar (SD) harus memiliki kemampuan menganalisis kebutuhan anak, mengambil keputusan apa yang harus dilakukan, merancang pembelajaran yang efektif dan efisien, mengaktifkan anak melalui motivasi eskatrinsik dan instrinsik, mengevaluasi hasil pembelajaran serta merevisi pembelajaran berikutnya agar lebih efektif dan dapat meningkatkan prestasi belajar anak. Sehingga keputusan yang diambil dapat dipertanggungjawabkan secara moral, ilmiah dan profesional selaku pendidik [3].

Mengingat peran guru yang sangat strategis perlu dibekali kemampuan yang sangat dibutuhkan selaku guru Sekolah dasar (SD) maka dilakukan kegiatan Pemantapan Kemampuan MMengajjar (PKM) guna untuk melatih dan membekali guru dengan kemampuan menyelenggarakan (mempersiapkan, merancang, melaksanakan, mengevaluasi dan memberbaiki pembelajaran di SD berdasarkan prinsip-prinsip keilmuan pendidikan anak usia sekolah dasar dan kependidikan keguruan yang dapat dipertanggungjawabkan kebenaarannya. [4]

Kegiatan Pemantapan Kemampuan Mengajar (PKM) mempunyai tujuan dasar untuk meningkatkan kemampuan gguru dalam merencanakan dan melaksanakan pembelajaran secara efektif dan efisien, dengan harapan guru dapat memiliki kemampuan [5]:

a. Mempersiapkan pemmbelajaran, termasuk mengenali karakteristik dan kebutuhan belajar peserta didik.

b. Menyususn rencana pembelajaran dengan menerapkan prinsip-prinsip pembelajaran dan keilmuan bidang studi dengan tepat.

c. Melaksanakan pembelajaran secara fektif dan efisien dengan mengacu pada rencana pembelajaran yang telah dibuat..

d. Mengidentifikasi kelebihan dan kelemahannya dalam mengajar, melalui reefleksi

e. Memperbaiki tindak pembelaajaran berikutnya dengan memperhatikan 
hasil evaluasi pembelajaran yang telah dilakukan sebelumnya.

f. Mempertanggungjawabkan keputusan dan tindak pembelajaran yang dilakukan berdasarkan prinsip-prinsip keilmuan dan moral yang diacunya.

Materi Pembelajaran PKM penekanannya pada merencanakan pembelajaran dan peningkatan penguasaan keterampilan dasar mengajar, diantaranya adalah keterampilan bertanya, memberi penguatan, mengadakan variasi, menjelaskan, membuka dan menutup pelajaran, membimbing diskusi, mengelola kelas dan keterampilan mengajar kelompok kecil ataupun perorangan.

Kesemua komponen tersebut perlu dikuasai oleh seorang guru dalam prooses pembelajaran yang diharapkan dapat meninngkatkan kemampuan profesional sebagai seorang guru. Hal ini sangat penting, profesi mengajar merupakan pekerjaan yang tidak mudah dilakukan, sebab dalam mengajar terkandung kemampuan menganalisis materi pembelajaran dan kebutuhan siswa, mengambil keputusan yang harus dilakukan merancang pembelajaran (RPP) yang efektif dan efeisien, mengaktifkan/memotivasi siswa untuk dapat belajar dengan sunguh-sungguh dan mengevaluasi proses dan hasil pembelajaran.

Selama proses pembelajaran berlangsung maka seorang guru selalu merefleksikan tugas yang telah dilakukkan, sebab guru yang baik adalah guru yang bersedia belajar dari apa yang telah dilakukannya, melihat dan mengakui kelemahan dan kekuatannya, berdialog dengan dirinya maupun teman sejawat yang seprofesi sebagai guru dan menerima masukan dari berbagai pihak.

\section{Permasalahan Mitra}

Berdasarkan hasil analisis diatas maka ditemukan permasalah mitra dimana masih kurangnya kesadaran guru-guru SD di Kecamatan Tomohon Tengah Kota Tomohon dalam meningkatkan kemampuan mengajar dalam berbagai aspek

\section{SOLUSI DAN TARGET LUARAN}

\section{Luaran dan Target Capaian}

Rencana Luaran

1. Mempersiapkan pemmbelajaran, termasuk mengenali karakteristik dan kebutuhan belajar peserta didik.

2. Menyususn rencana pembelajaran dengan menerapkan prinsipprinsip pembelajaran dan keilmuan bidang studi dengan tepat.

3. Melaksanakan pembelajaran secara fektif dan efisien dengan mengacu pada rencana pembelajaran yang telah dibuat.. 
4. Mengidentifikasi kelebihan dan kelemahannya dalam mengajar, melalui reefleksi

5. Memperbaiki tindak pembelaajaran berikutnya dengan memperhatikan hasil evaluasi pembelajaran yang telah dilakukan sebelumnya.

6. Mempertanggungjawabkan keputusan dan tindak pembelajaran yang dilakukan berdasarkan prinsip-prinsip keilmuan dan moral yang diacunya.

Solusi yang ditawarkan mengatasi permasalahan ini adalah dilakukannya pelatihan dalam meningkatan kamampuan memgajar guru-guru SD di Kecamatan Tomohon Tengah Kota Tomohon, yang terinci sebagai berikut:

1. Pemaparan Konsep Pengembangan Media Pembelajaran menggunakan Power Point

2. Pemaparan mengenai metode pembelajaran aktif, dan

3. Penyusunan

Rencana

Pembelajaran

\section{METODE PELAKSANAAN}

Dengan memperhatikan permasalahan yang ada, pendekatan yang digunakan untuk PKM adalah metode pemberdayaan masyarakat partisipatif atau Participatory Rural
Apraissal (PRA), yang dilaksanakan dalam bentuk wokshop pelatihan dan pendampingan dalam pengembangan metode dan perangkat pembelajaran lainnya. Pelaksanaan PKM ini target dan luarannya terhadap mitra adalah meningkatnya kompetensi guru dalam meningkatkan kemampuan mengajar dengan Mempersiapkan pemmbelajaran termasuk mengenali karakteristik dan kebutuhan belajar peserta didik, Menyususn rencana pembelajaran dengan menerapkan prinsip-prinsip pembelajaran dan keilmuan bidang studi dengan tepat., Melaksanakan pembelajaran secara fektif dan efisien dengan mengacu pada rencana pembelajaran yang telah dibuat, Mengidentifikasi kelebihan dan kelemahannya dalam mengajar, melalui reefleksi, Memperbaiki tindak pembelaajaran berikutnya dengan memperhatikan hasil evaluasi pembelajaran yang telah dilakukan sebelumnya dan Mempertanggungjawabkan keputusan dan tindak pembelajaran yang dilakukan berdasarkan prinsip-prinsip keilmuan dan moral yang diacunya.

\section{HASIL DAN PEMBAHASAN}

Pengembangan Media Power Point dalam Pembelajaran

Tujuan dari kegiatan ini adalah supaya mitra (guru) bisa mengoptimalkan media pembelajaran melalui pengembangan media power point. Sehingga diharapkan melalui 
pemdampingan ini memudahkan bagi guru dalam menyamaikan pesan-pesan pembelajaran kepada peserta didik, demikian juga peserta didik dengan adanya media ini lebih terbantu dalam memahami materi pembelajaran yang disampaikan guru. Dalam kegiatan ini para guru praktik secara langsung, dengan dua titik fokus yang diutamakan. Fokus yang pertama adalah bagaimana cara membuat file presentasi (media power point) dengan menarik. Sedangkan fokus yang kedua adalah pendampingan tentang hyperlink dalam power point. Demikian juga disampaikan dalam pendampingan, tentang beberapa langkah supaya file presentasi (power point) lebih menarik, diantaranya adalah pemilihan warna, penggunaan fitur desain yang ada pada power point (shape, smart art, chart, dll).

\section{Pengembangan Metode Pembelajaran} Aktif

Metode yang dilaksanakan dalam pendampingan ini adalah metode ceramah, tanya jawab, diskusi, demontrasi, dan unjuk kerja. Tim pengabdian membagi pendampingan ini ke dalam beberapa sessi. Sessi yang pertama adalah penyampaian materi tentang macam-macam metode pembelajaran. Diawali dengan mengidentifikasi macam- macam metode yang sudah sering dilakukan oleh mitra pada waktu kegiatan pembelajaran. Selanjutnya Tim memberikan materi macam-macam metode dengan menggunakan pijakan metode pembelajaran Active Learning. Untuk lebih efisien dan membangun rasa kerjasama maka mitra dibagi menjadi empat kelompok. Masing-masing kelompok mendiskusikan modul metode pembelajaran yang dibagikan oleh Tim pengabdian. Dalam modul tersebut terdapat beberapa macam contoh media pembelajaran yang harus dikuasai oleh mitra. Diantaranya ada metode market place activity, mind mapping, think pair and share, poster comment, dll. Setelah penyampaian materi selesai, sessi selanjutnya adalah diskusi. Diskusi dilakukan untuk saling berkomunikasi antar anggota kelompok berbagi ide-ide kreatif. Dengan menggunakan metode poster comment masing-masing kelompok diberikan sebuah gambar kemudian untuk memberikan komentar terbaik di bawah gambar tersebut. Setelah selesai gambar tersebut dipresentasikan dan ditempelkan di dinding.

\section{Penyusunan Perencanaan Pembelajaran}

Perangkat pembelajaran adalah seperangkat dokumen-dokumen yang digunakan seorang guru sebagai patokan dalam pembelajarannya. Perangkat pembelajaran bisa dikatakan sebagai alat memasak bagi seorang guru. Maka ia harus mempersiapkan alat memasaknya sebelum ia mengajar. Diantara perangkat pembelajaran seorang guru adalah adanya RPP, Silabus, Program semester, program tahunan, dafta nilai, dan lain sebagainya. Pada pendampingan ini, Tim memfokuskan 
pendampingan pada penyusunan perangkat pembelajaran yang berupa Rencana Pelaksanaan Pembelajaran (RPP) sesuai kurikulum 2013 revisi 2017. Namun sebelum praktik menyusun RPP, Tim Pengabdian melakukan refresing tentang materi kurikulum 2013 dan revisi tahun 2017. Hasil perbaikan berkenaan dengan (1) Koherensi KI-KD dan penyelarasan dokumen; (2) Penataan kompetensi Sikap Spiritual dan Sikap Sosial pada semua mata pelajaran; (3) Penataan kompetensi yang tidak dibatasi oleh pemenggalan taksonomi proses berpikir (berpikir tingkat tinggi sejak SD); (4) Pemberian ruang kreatif kepada guru dalam mengimplementasikan kurikulum. (BPP, 2017).

Perbaikan atau revisi Kurikulum 2013 tahun 2017, juga mengintegrasikan (1) Penguatan Pendidikan Karakter (PPK) di dalam pembelajaran. Karakter yang diperkuat terutama lima karakter, yaitu: religius, nasionalis, mandiri, gotong royong, dan integritas; (2) Literasi, Pengertian Literasi dalam konteks Gerakan Literasi Sekolah (GLS) adalah kemampuan mengakses, memahami, dan menggunakan sesuatu secara cerdas melalui berbagai aktivitas antara lain membaca, melihat, menyimak, menulis, dan/atau berbicara; (3) Keterampilan abad 21 atau diistilahkan dengan 4C (Creative, Critical thinking, Communicative, dan Collaborative). $4 \mathrm{C}$ adalah jenis softskill yang pada implementasi keseharian, jauh lebih bermanfaat ketimbang sekadar pengusaan hardskill; (4) HOTS (Higher Order Thinking Skill) adalah kemampuan berpikir kritis, logis, reflektif, metakognitif, dan berpikir kreatif yang merupakan kemampuan berpikir tingkat tinggi. (BPP, 2017) Setelah refressing terhdap perubahan kurikulum tahun 2017 dilanjutkan dengan penyusunan RPP dengan menggunakan prinsip learning by doing. Tim pengabdian dengan terlebih dahulu memberikan panduan format langkah-langkah menyusun RPP. Dalam menyusun RPP yang perlu dipersiapkan guru adalah kurikulum yang memuat tentang Kompetensi inti, standar kompetensi, materi, dan alokasi waktu. Kemudian dilanjutkan dengan penjelasan komponen yang ada pada Rencana Pelakasanaan Pembelajaran (RPP). Komponen yang ada pada RPP diantaranya adalah Identitas, Kompetensi inti, Kompetensi dasar dan Indikator, Tujuan Pembelajaran, Materi Pembelajaran, Metode Pembelajaran, Media Pembelajaran, Sumber belajar, Langkah-langkah pembelajaran, penilaian hasil belajar, dan Lampiran. Dari kesemua komponen yang ada, semuanya dijelaskan satu persatu tentang langkahlangkah penyusunan, konten, serta beberapa revisi yang sudah berlaku.

Setelah penyampaian materi selesai, kegiatan selanjutnya adalah kegiatan tanya jawab. Para peserta workshop dipersilahkan untuk menanyakan beberapa pertanyaan kepada Tim Pengabdian. Kegiatan dialog 
terjadi dengan santai namun tetap serius. Ketika dialog dirasa sudah cukup kegiatan selanjutnya adalah praktek penyusunan RPP. Kegiatan praktek penyusunan RPP menggunakan metode praktik dan diskusi.

Dari semua peserta yang ada dibagi ke dalam empat kelompok. Kemudian masing-masing kelompok menganalisis terhadap RPP yang telah dipersiapkan terlebih dahulu. Setelah masing-masing kelompok menyelesaikan analisisnya, mereka dipersilahkan untuk mempresentasikan hasilnya ke depan kelas. Kemudian kelompok yang lain memberikan tanggapan.

Proses selanjutnya setelah menganalisis RPP, masing-masing kelompok langsung mempraktekkan penyusunan RPP. Pemilihan materi disesuaikan dengan basic kemampuan kebanyakan dari anggota kelompok. Selama proses penyusunan, Tim pengabdian selalu mendampingi. Jika ada hal-hal yang perlu ditanyakan siap untuk membantu peserta workshop. Hasil dari pendampingan penyusunan perangkat pembelajaran ini adalah mitra bisa mengaplikasikan penyusunan RPP kurikulum 2013 dengan baik.

\section{KESIMPULAN.}

Kegiatan PKM telah dilaksanakan dengan lancar dan baik serta telah memberikan pengetahuan dan keterampilan dalam bidang Penyusunan Rencana Pembelajaran, Pengembangan Metode Pembelajaran Aktif dan pengembangan Media Power Point dalam Pembelajaran. Para peserta yang merupakan Guru-guru SD di Kecamatan Tomohon Tengah Kota Tomohon terlihat antusias dalam berpartisipasi dikegiatan Pelatihan untuk Meningkatkan Kemampuan Mengajar Guru SD. Keberhasilan dalam PKM ini tercermin pada guru yang: a). memiliki pengetahuan dan pemahaman tentang metode pembelajaran aktif; (b) memiliki pengetahuan dan pemahaman tentang mengembangkan media powerpoint dalam pembelajaan; (c) memiliki pengetahuan, pemahaman dan praktik tentang menyususn RPP.

\section{REFERENSI}

[1] Ridwan,"Pendidikan Agama Membangun Moral http://ridwan202.com/2015/02/20/ Pendidikan Agama-Membangun-Moral

[2] Oemar Hamalik, Pendidikan Guru Berdasarkan Pendekatan Kompetensi, Cet Ke-4, Jakarta: Bumi Aksara, 2006

[3] Nana Sudjana, Dasar-Dasar Proses Belajar Mengajar, Bandung: Sinar Baru, 1989

[4] Tilaar.Manajemen Pendidikan Nasional. Bandung : PT. Remaja Rosdakarya.1999.

[5] Tim Broad-Based Education. Konsep Pendidikan Berorientasi Kecakapan Hidup (life Skill) Melalui Pendekatan Pendidikan Berbasis Luas (Broad-Based EducationBBE). Jakarta : Depdiknas. 2002 